\title{
Nutrition and neurodevelopment: mechanisms of developmental dysfunction and disease in later life
}

\author{
M. J. Dauncey* and R. J. Bicknell \\ Developmental Genetics Programme and Neurobiology Programme, The Babraham Institute, \\ Cambridge CB2 4AT, UK
}

\begin{abstract}
Nutrition plays a central role in linking the fields of developmental neurobiology and cognitive neuroscience. It has a profound impact on the development of brain structure and function and malnutrition can result in developmental dysfunction and disease in later life. A number of diseases, including schizophrenia, may be related to neurodevelopmental insults such as malnutrition, hypoxia, viruses or in utero drug exposure. Some of the most significant findings on nutrition and neurodevelopment during the last three decades, and especially during the last few years, are discussed in this review. Attention is focused on the underlying cellular and molecular mechanisms by which diet exerts its effects. Randomized intervention studies have revealed important effects of early nutrition on later cognitive development, and recent epidemiological findings show that both genetics and environment are risk factors for schizophrenia. Particularly important is the effect of early nutrition on development of the hippocampus, a brain structure important in establishing learning and memory, and hence for cognitive performance. A major aim of future research should be to elucidate the molecular mechanisms underlying nutritionally-induced impairment of neurodevelopment and specifically to determine the mechanisms by which early nutritional experience affects later cognitive performance. Key research objectives should include: (1) increased understanding of mechanisms underlying the normal processes of ageing and neurodegenerative disorders; (2) assessment of the role of susceptibility genes in modulating the effects of early nutrition on neurodevelopment; and (3) development of nutritional and pharmaceutical strategies for preventing and/or ameliorating the adverse effects of early malnutrition on long-term programming.
\end{abstract}

Neurodevelopment: Fetal nutrition: Infant nutrition

\section{Introduction}

The last few years have seen considerable renewed interest in determining the extent to which suboptimal health and illness in adulthood can be traced to early environmental experience (Lucas, 1994; Barker, 1995; Dauncey, 1997; Fernald \& Grantham-McGregor, 1998; Fowden et

\footnotetext{
Abbreviations: AA, arachidonic acid; BDNF, brain-derived neurotropic factor; DHA, docosahexaenoic acid; GAP, growth-associated protein; IQ, intelligence quotient; MAP, microtubule-associated protein; NMDA, $N$-methyl-D-aspartate.

*Corresponding author: Dr M. J. Dauncey, fax + 44 (0) 1223 496032, email joy.dauncey@bbsrc.ac.uk
} 
al. 1998; Nyirenda \& Seckl, 1998; Hoet \& Hanson, 1999; Wauben \& Wainwright, 1999). Evidence demonstrates that cognitive performance can be modified by early nutrition and recent advances in developmental neurobiology and cognitive neuroscience have suggested several mechanisms which mediate this effect. This present review discusses some of the key studies on nutrition and neurodevelopment which have been undertaken in both human subjects and other animals during the last 30 years. A comparative approach enables a much more comprehensive understanding than would be possible by addressing studies in human subjects alone. It allows not only the separation of nutritional influences from those due to genetics or other environmental factors, but also a more detailed understanding of underlying regulatory mechanisms. An extremely wide range of nutritional approaches has been used in different studies and these include modifications in maternal, neonatal and postnatal diets in relation to both macronutrients and micronutrients. Attention is therefore drawn to some of the marked differences in nutritional manipulation, in relation to timing, magnitude and extent, because these in turn can have a striking impact on outcome. In line with the development of increasingly sophisticated neurobiological techniques, a broadly chronological approach is taken, with particular attention focusing on the last decade.

Many aspects of neurodevelopment may be modified by early nutrition. This present review focuses on the cortex and especially the hippocampus (Fig. 1) because of their importance in cognitive functioning, learning and memory. This is relevant not only to intelligence quotient (IQ) but also to the development of diseases, including schizophrenia, which are thought to be related to neurodevelopmental insults such as malnutrition, hypoxia, viruses or exposure to drugs in utero. Considerable evidence indicates that the prefrontal cortex is a site of dysfunction in schizophrenia and the apparent absence of gross structural abnormalities suggests that there may be more subtle disturbances in prefrontal cortical circuitry, at the level of the synapse (Glantz \& Lewis, 1997). The extent to which early nutrition may influence the brain at many levels, including cell populations, synaptic connectivity and neurotransmission is therefore discussed in this present review.

\section{0s to 1980 s}

\section{Critical periods of development}

The importance of nutrition in brain development and the possibility of effects on behaviour and intelligence has long been recognized. A number of studies on critical periods in brain

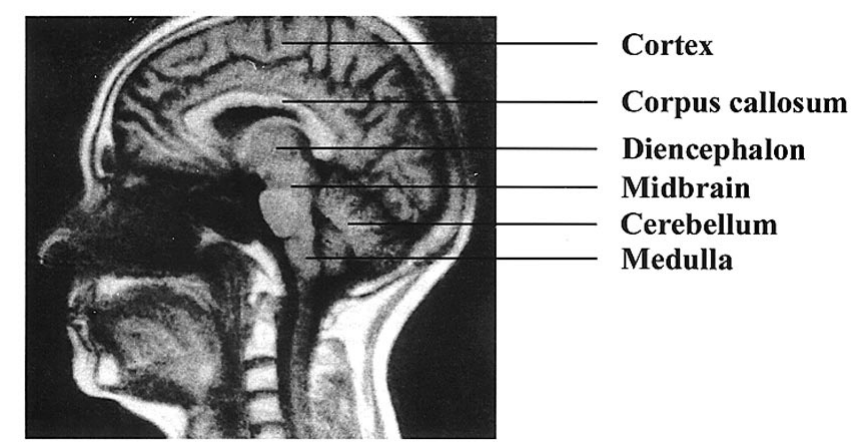

Fig. 1. A mid-sagittal view of the human brain obtained by magnetic resonance imaging (MRI). Some of the major brain structures are indicated. The hippocampus lies below the corpus callosum, a fibre bundle that connects the left and right hemispheres of the brain. Modified from Kandel \& Schwartz (1985). 
development and the vulnerability of the developing brain to undernutrition were undertaken several decades ago and these are discussed in excellent reviews by several key workers in the field (Stewart, 1974; Dobbing, 1990; Smart, 1990, 1991). This work demonstrated marked species differences which were related to relative stage of maturity at birth, for example with the rat being born at a much earlier stage of neurodevelopment than the human. The course of brain development can be affected by a variety of factors, with the nature and extent of the perturbation being dependent on the timing of the treatment with respect to the stage of brain development. Aspects of growth completed before treatment are unaffected. Only those events occurring at the time of the treatment are affected, together with some later-occurring events, as the result of a cascade of effects. It was concluded that 'undernutrition appears to depress the rate of all brain growth events contemporaneous with it to the same extent' (Smart, 1991). The extent of recovery on refeeding varies from none, through partial, to complete, depending on the process under consideration and the timing and severity of the undernutrition.

\section{Methods: diet and neurodevelopmental assessment}

The focus in the 1970s was on the immediate effects of nutrition on neurodevelopment, although some studies did determine whether early nutrition could induce long-term changes. There was a striking range of nutritional treatments and assessments of neurodevelopment, as illustrated by reference to the following studies, which highlight the complexity of the topic and hence the continuing difficulty in linking behavioural performance with precise nutritional deficiencies and neurobiological defects. Chronic protein malnutrition of mother and offspring was induced by feeding female rats a low $(80 \mathrm{~g} / \mathrm{kg})$ or control $(250 \mathrm{~g} / \mathrm{kg})$ protein intake, from 5 weeks before conception and throughout gestation and lactation (Forbes et al. 1975). After weaning, pups were fed on the same diets as their mothers and electrically-evoked responses were measured under anaesthesia at 13,21 and 60-66 d. Evoked response latency was significantly greater in malnourished animals at $13 \mathrm{~d}$, but no differences were seen in adults. Results were interpreted as demonstrating a dietary effect on ontogeny of cortical evoked potentials, independent of any possible effect on sensory receptor mechanisms.

In a second study, the food intake of female rats was restricted to $50 \%$ of the ad libitum stock diet of controls (C); one restricted group was fed stock diet (M1), the other was fed on casein-supplemented stock diet containing $660 \mathrm{~g}$ protein/kg (M2). After weaning at $21 \mathrm{~d}$, all progeny were fed on stock diet ad libitum for 2 weeks (Atallah et al. 1977). At 5 weeks, M1 had lowest brain weights. The lower birth weight but normal brain size of M2 suggested that some of the protein consumed by M2 dams was conserved for synthesis of 'vital components' despite energy restriction.

In a third study, postnatal undernutrition was induced by removing the mother from the rat pups for part of each day from birth, and undernutrition was continued from weaning by restricting daily food intake until $60 \mathrm{~d}$ (Krigman \& Hogan, 1976). Major differences were observed in brain and body weights. At the peak of myelination in controls $(20 \mathrm{~d})$, the proportion of myelinated axons was reduced, myelin sheaths were thinner and there was a deficit in the relatively myelin-specific galactolipids. In general, the effect of undernutrition was one of inhibited and somewhat retarded myelination, mostly as a result of a reduction in the number of myelinating glia formed. One should note, however, that the methodology before weaning involved maternal separation, which itself has a significant impact on behavioural responses in adulthood (Matthews et al. 1996). 


\section{Early diet and later cognitive function}

The extent to which early diet affects later cognitive function has been addressed by numerous experimental studies in animals and epidemiological studies in human subjects (Stewart, 1974; Grantham-McGregor et al. 1987). Many animal studies have shown clear effects of early nutrition on later brain structure and behaviour. However, most human studies have been nonrandomized and concern malnourished individuals from developing countries where it is difficult to separate the specific effects of early malnutrition from those due to other contributory factors. Moreover, no definitive data are available on the effects of prenatal human nutrition. However, the long-term prospective randomized studies on preterm infants undertaken by Lucas's group are especially important because they have provided unique evidence that as little as 4 weeks of early dietary manipulation may have profound effects on cognitive and neurological status (Lucas et al. 1989). Low birth-weight infants received preterm formula or unfortified donor breast-milk as supplements to their mothers' expressed milk. Surviving infants were assessed at 9 months after their expected date of delivery. An overall developmental quotient was calculated from assessment of five types of behaviour: adaptive, gross motor, fine motor, language and personal-social, which were then adjusted for prematurity. The mean developmental quotient was lower in those fed on donor breast-milk as the supplement and the disadvantage was greatest after fetal growth retardation. It was concluded that the diet used for low birth-weight infants over a brief, but perhaps critical, postnatal period has developmental consequences that persist into infancy. Moreover, infants who are small-forgestational-age are especially vulnerable to suboptimal nutrition.

\section{Undernutrition and neurodevelopment}

Two detailed reviews described the major impact which undernutrition has on brain development and neurotransmission (Wiggins et al. 1984; Zeisel, 1986). Not only do both short-term and long-term changes in diet influence neurotransmission, but starvation can impair neuronal maturation and have lasting effects on behaviour and intellectual performance. Indeed, many aspects of brain development are affected, including transmitter synthesis, degradation and receptor sites. Because many neuropsychiatric conditions can be traced to dysfunction in synaptic neurochemistry, it is possible that some of the central nervous system abnormalities which result from childhood undernutrition may be a consequence of a modification in synaptic biochemistry.

Alterations in serotonin-mediated neurotransmission have been implicated in a number of psychiatric conditions. Therefore, especially important was an investigation on the effects of postnatal undernutrition on the serotonin neurone system in the developing brain (Ishimura et al. 1989). Undernutrition was induced in mice by increasing litter size from six to eighteen during the first 3 weeks postnatally. At $15 \mathrm{~d}$ a morphological change, described as a large swelling of serotonin-immunoreactive neurones, was noted in various parts of the brain, but there were no marked changes in dendrites and cell bodies. Moreover, quantitative immunohistochemical analysis at $60 \mathrm{~d}$ showed a significant decrease in serotonin-immunoreactive cell bodies in several key regions of the brain. Environmental enrichment may aid recovery from behavioural deficits associated with early malnutrition and therefore another study investigated whether corresponding neuroanatomical changes could be detected (Carughi et al. 1989). Environmental enrichment during nutritional rehabilitation of rats was found to enhance dendritic branching and thickness of the occipital cortex. 
Protein malnutrition and developmental neurophysiology

The hippocampal formation (Fig. 2) comprises the hippocampus, dentate gyrus and the subiculum, a major input-output structure. On the basis of cell type and neural connections, the hippocampus is divided into three longitudinal areas, CA1, CA2 and CA3, consisting of pyramidal output cells. The neighbouring dentate gyrus consists of granule input cells. Inputs reach the hippocampus through the perforant path which synapses with both the CA3 pyramidal cells and the granule cells; the latter project via the mossy fibres to the CA3 cells, which in turn project to the CA1 pyramidal cells and hence to the subiculum.

A substantial body of information on the effects of protein malnutrition on cortical and hippocampal electroencephalograms, assessed by power spectral analysis, has been obtained by Austin, Bronzino, Galler, Morgane and colleagues (Bronzino et al. 1980, 1983, 1986; Morgane et al. 1985). Additional assessment has been made of synaptic potentiation in dentate gyrus (Austin et al. 1986) and of electrographic and behavioural measures of hippocampal kindling (Bronzino et al. 1986), a state in which neuronal excitability is enhanced, facilitating an epileptic seizure. Overall, this group has carried out a large number of studies in the field and continues to make significant contributions. Dietary manipulation has focused on: (1) rats fed on a low-protein or control diet during the week before weaning (14-22 d), immediately after weaning (22-23 d) and during adulthood (90-120 d); and (2) prenatal protein malnutrition: rats born to dams fed on a low-protein or control diet during gestation and lactation and maintained on the diet of the dam after weaning. In general, the dietary paradigm involved giving animals ad libitum access to isoenergetic diets $(18.0 \mathrm{~kJ} / \mathrm{g}$ ) containing 60 or $80 \mathrm{~g}$ casein $/ \mathrm{kg}$ (low-protein diet) or $250 \mathrm{~g}$ casein $/ \mathrm{kg}$ (control diet). Casein was the only source of protein and was fortified with methionine. It contained $870 \mathrm{~g}$ protein $/ \mathrm{kg}$ and hence the low-protein diets provided 50 or

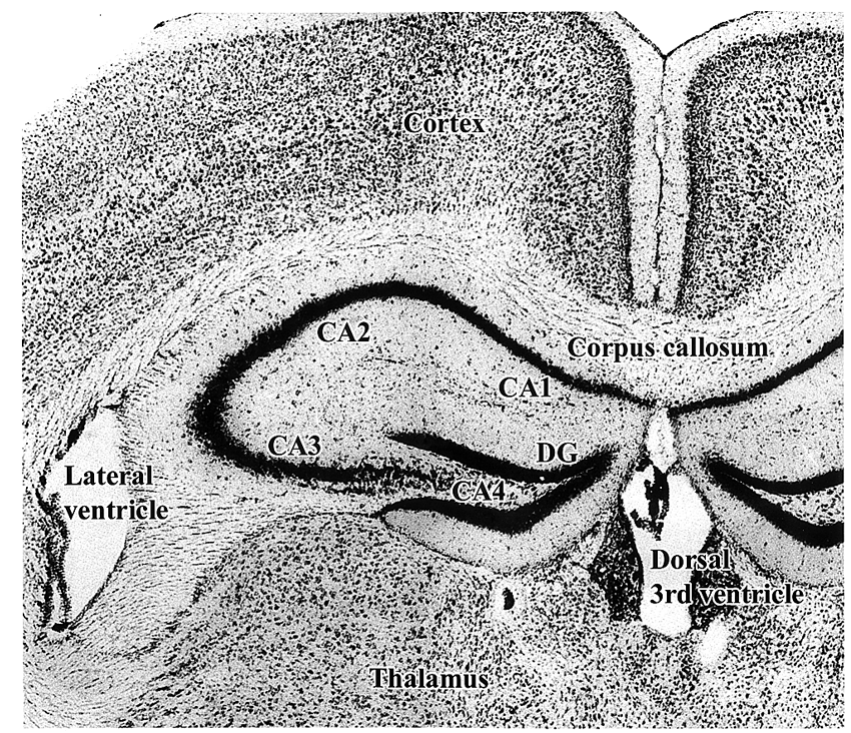

Fig. 2. Coronal section of the mouse brain illustrating the main areas of the hippocampal formation. The dorsal third ventricle lies in the mid-line and only one side of the hippocampus (a bilateral structure) is shown. CA1-CA4, hippocampal areas; DG, dentate gyrus. Modified from Franklin \& Paxinos (1997). 
$70 \mathrm{~g}$ protein $/ \mathrm{kg}$ and the control diet provided $220 \mathrm{~g}$ protein $/ \mathrm{kg}$ (Stern et al. 1974; Bronzino et al. 1980, 1986). In some cases, nutritional rehabilitation of the pups occurred from birth, while in others, protein malnutrition was continued in the progeny. A major finding in the 1980s was that prenatal protein malnutrition alters the response of hippocampal CA1 neurones to electrical stimulation, and this alteration resulted in marked changes to both the electrographic and behavioural correlates of kindling (Bronzino et al. 1986).

\section{Impact of maternal and perinatal undernutrition on neuroanatomy}

Studies on the effects of maternal undernutrition focused on myelination, gliogenesis and glial maturation in rat corpus callosum (Lai \& Lewis, 1980; Lai et al. 1980). The retardation in myelin acquisition seemed to be related to a delay in the differentiation of oligodendroglia and also to a disturbance in their proliferation. Intrauterine malnutrition and hypoxia also have long-term effects on brain cell number and cell size, probably via alteration in fetal mitotic rate (Meberg, 1981). Daily mother-litter separation, which involves both dietary and sensory deprivation, results in long-term alterations in the maternal behaviour of the neonatally undernourished rats (Salas et al. 1984). This indicates that environmental influences related to food intake and sensory stimulation, interacting at critical stages of brain development, are essential for the maturation of adult behavioural patterns. Moreover, it was also found that reductions in maternal food and water intake can account for prenatal stress effects on neurobehavioural development of mice (Ward \& Wainwright, 1988).

To determine whether the reported effects of early life undernutrition on brain morphology are due to alterations in mother-infant interactions and not directly to undernutrition, synapseto-neurone ratios were estimated in the visual cortex of adult rats after undernutrition during normal or artificial rearing (Bedi et al. 1989). It was found that environmental isolation was not, by itself, enough to cause permanent changes in interneuronal connectivity; concurrent undernutrition induced a reduction in synapse-to-neurone ratio. The extent to which the adverse effects of early nutrition can be ameliorated was investigated in male rats which were undernourished from birth to $30 \mathrm{~d}$ and then nutritionally rehabilitated until $160 \mathrm{~d}$ (Bedi et al. 1980; Thomas et al. 1980). Quantitative stereological procedures at the light and electron microscopical levels were used to estimate synapse-to-neurone ratio in the frontal cortex and granular layer of the cerebellum. Large deficits in synapse-to-neurone ratio in certain brain regions due to early postnatal undernutrition showed some degree of catch-up in later life.

\section{0 to 1995}

\section{Critical periods in brain development}

Based on the original hypothesis, that undernutrition depresses the growth rate of all processes in the brain contemporaneous with it to the same extent (Peeling \& Smart, 1994a), it was predicted that severe undernutrition during the sucking period would leave capillarity unaffected but would result in a deficit in synapse-to-neurone ratio of similar magnitude to that in brain weight (Peeling \& Smart, 1994b). At birth, rats were fostered and either well-fed to $30 \mathrm{~d}$ or undernourished to the same age by underfeeding their foster mothers. Findings were in good agreement with the hypothesis. Undernutrition resulted in a $21 \%$ deficit in brain weight and a $22 \%$ deficit in the number of synapses per neurone in the visual cortex; neurone density was 
elevated by $19 \%$ and capillarity, as the fraction of section area occupied by capillary lumen, appeared to be completely unaffected by nutrition.

\section{Prenatal malnutrition and postnatal brain structure and function}

Two comprehensive reviews on prenatal malnutrition and development of the brain pointed out that nutrition is probably the single greatest environmental influence on the fetus and neonate and plays a role in the maturation and functional development of the central nervous system (Morgane et al. 1993; Tonkiss et al. 1993). Prenatal protein malnutrition adversely affects the developing brain in numerous ways, depending largely on its timing in relation to various developmental events in the brain, and to a lesser extent on the type and severity of the deprivation. Many of the effects of prenatal malnutrition are permanent, though some degree of amelioration may be produced by exposure to stimulating and enriched environments. Malnutrition exerts its effects during development, not only during the most rapid period of brain growth but also during early organizational events such as neurogenesis, cell migration and differentiation. It can result in a variety of syndromes with minimal brain dysfunction and ultimately affects attentional processes and interactions of the organism with the environment, often leading to learning disabilities. With respect to brain development, there are distorted relations between neurones and glia, poor formation of neuronal circuits and alterations of normal regressive events, including cell death and axonal and dendritic pruning. Moreover, there are alterations in normal age-related sequences of brain maturation, especially affecting coordinated development of various cell types and, eventually, the formation of neuronal circuits and activation of neurotransmitter systems. Clearly, such a broad range of defects can be assessed adequately only by multidisciplinary investigations at the behavioural, physiological, cellular and molecular levels.

Specific effects of protein malnutrition during gestation on postnatal neurophysiology were investigated by feeding rat dams 60 or $250 \mathrm{~g}$ casein/ $\mathrm{kg}$ diet (equivalent to 50 and $220 \mathrm{~g}$ protein/ $\mathrm{kg}$ respectively) during gestation and then fostering pups to lactating dams on the $250 \mathrm{~g}$ casein/ $\mathrm{kg}$ diet $24 \mathrm{~h}$ after birth and maintaining them on this diet after weaning (Bronzino et al. 1990, 1991a,b; Austin-Lafrance et al. 1991; Shultz et al. 1995). At 90-120d, electrographic and behavioural responses to electrical kindling of the medial perforant pathway were determined. Dietary protein rehabilitation from birth was found to be incapable of reversing or significantly ameliorating the effects of gestational protein deficiency on susceptibility to seizure activity and acquisition of the kindled state. This indicated that prenatal protein deficiency results in long-lasting changes in neuronal systems in the hippocampal formation which are involved in both the electrographic and behavioural correlates of the kindling process.

Fig. 3 illustrates the structure of typical presynaptic and postsynaptic neurones and the specific anatomical regions which may be subject to modification by nutrition. Prenatal protein malnutrition followed by postnatal rehabilitation results in long-term differential morphological changes in rat CA3 hippocampal pyramidal cells (Diaz-Cintra et al. 1994). Female rats were fed on either 60 or $250 \mathrm{~g}$ casein/kg diet from 5 weeks before conception and after delivery pups were cross-fostered to dams fed on $250 \mathrm{~g}$ casein $/ \mathrm{kg}$ diet and maintained on that diet until 15,30, 90 or $220 \mathrm{~d}$ postnatally. There were decreases in somal size at 90 and $220 \mathrm{~d}$, length of apical dendrites at $15 \mathrm{~d}$, apical and basal dendritic branching at $15 \mathrm{~d}$ and 15, 90 and $220 \mathrm{~d}$ respectively, and spine density at 30,90 and $220 \mathrm{~d}$. Apical dendritic branching was increased at 90 and $220 \mathrm{~d}$. The extent to which CA1 hippocampal pyramidal cells are also influenced by nutrition is described later in this present review. 


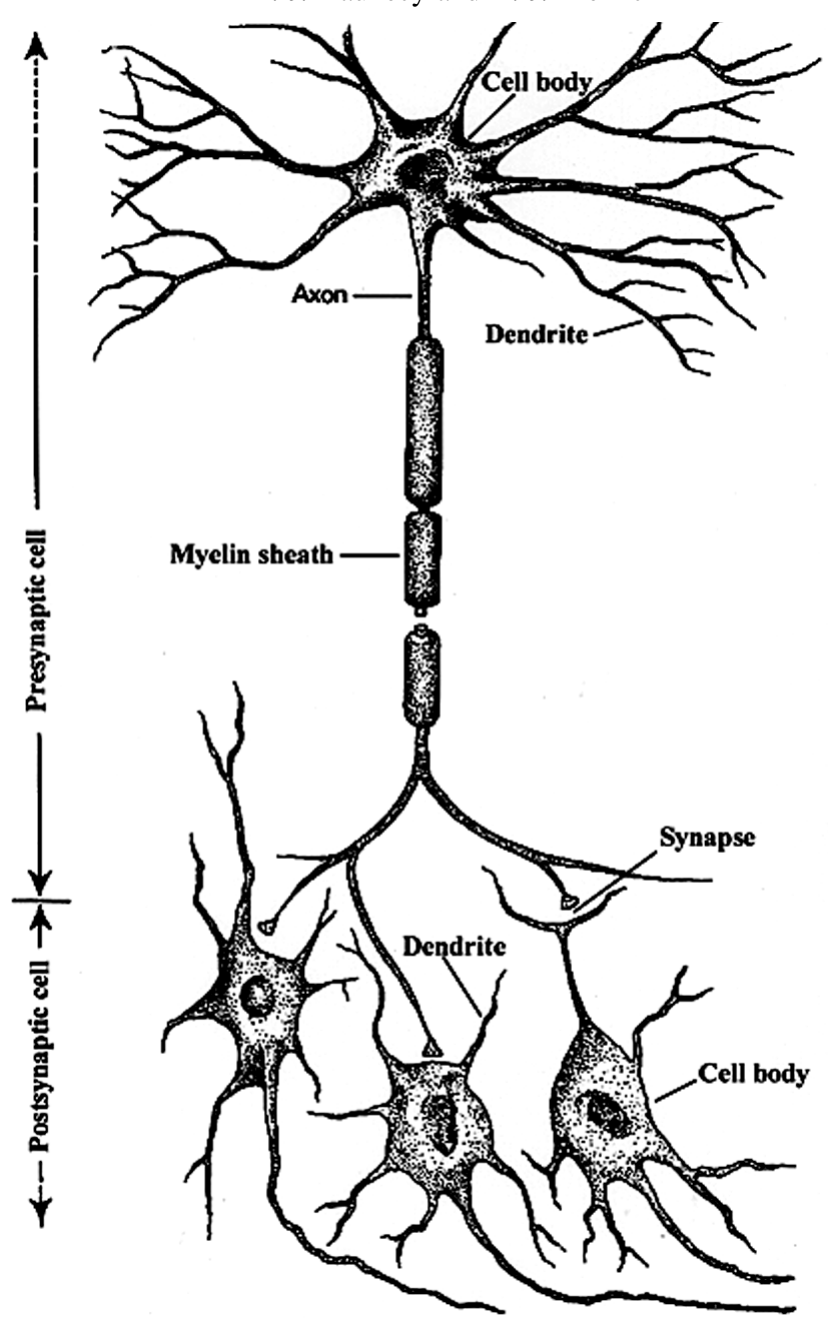

Fig. 3. Illustration of the main features of a typical neurone. Axons vary greatly in length and may be insulated by a fatty myelin sheath. The terminal branches of axons form synapses with multiple other 'postsynaptic' neurones, usually on their dendrites or cell body. Adapted from Kandel \& Schwartz (1985).

\section{Neonatal and postnatal nutrition}

Low birth-weight and preterm infants. Nutritional requirements of very low birth-weight infants have been assessed in relation to a wide range of outcomes, including abnormal neurological outcome, if not fed adequately (Hay, 1994). It is clear that their nutritional requirements need to be defined more accurately, especially in the period soon after birth, to reduce to a minimum any nutritional and growth deficits and hence to prevent any potential neurodevelopmental handicaps from developing.

During this period, the influence of early postnatal nutrition on neurodevelopment and cognitive function continued to be addressed by Lucas's group (Lucas et al. 1992; Lucas, 1994; Morley \& Lucas, 1994; Morley, 1996). Children aged 7.5 to 8 years old, who had been born 
preterm and randomly assigned a standard milk formula rather than preterm formula for one month, with both groups fed the same thereafter, had a major reduction in verbal IQ together with an increased risk of cognitive impairment and frank cerebral palsy; there was an 8-fold difference between groups. Studies on rats and primates suggest that the brain may be able to reorganize and achieve functional compensation if cortical damage occurs at an early stage of development (Kolb \& Whishaw, 1989; Kolb \& Gibb, 1990). Thus, although cerebral palsy in preterm children may originate prenatally or before the start of enteral feeding, the brain may be able to compensate functionally if subsequent nutrition is adequate. In general, males are more at risk from early nutritional insults than females and in the studies described above boys were most affected by diet. Children fed on the term rather than the preterm formula had a 15 point deficit in verbal IQ, and a 10 point deficit in overall IQ, with outcome being directly related to food intake. Overall, preterm infants who had consumed mother's milk in the early weeks of life had a higher IQ than those who received no maternal milk and an advantage remained even after adjustment for differences in mother's education and social class. It was concluded that although this may be due in part to differences in parenting skills or genetic potential, it pointed to a beneficial effect of human milk on neurodevelopment.

Fatty acids and neurodevelopment. A retrospective study on neurological differences between 9-year-old children born at term and fed on either breast milk or formula-milk as babies also suggested a beneficial effect of breast-feeding on brain neurological development (Lanting et al. 1994). It was concluded that longer-chain polyunsaturated fatty acids, which are present in breast-milk but not in most formula milks, may have a role in this response. Many studies have been undertaken on milk composition, especially in relation to fatty acids and brain development in human subjects and experimental animals, and these are discussed extensively elsewhere (Crawford et al. 1989, 1993; Farquharson et al. 1992; Martinez, 1992; Innis, 1994; Makrides et al. 1994; de Andraca \& Uauy, 1995; Uauy \& de Andraca, 1995; UauyDagach \& Mena, 1995; van Houwelingen et al. 1995; Lanting \& Boersma, 1996).

The n-3 and $n-6$ families of long-chain polyunsaturated fatty acids are derived from $\alpha$ linolenic acid and linoleic acid respectively, and their metabolites include docosahexaenoic acid (DHA; 22:6n-3) and arachidonic acid (AA; 20:4n-6). The long-chain polyunsaturated fatty acids, and especially AA and DHA, are accumulated in large amounts in the membrane phospholipids of the developing central nervous system (Innis, 1994). Together with other 20-C long-chain fatty acids, AA is a precursor of the eicosanoids, including prostaglandins, which in turn play a key role in regulating normal brain function (Wauben \& Wainwright, 1999). Moreover, AA can be released from the cell membrane and may act as a second messenger involved in synaptic plasticity. Changing the fatty acid composition of brain phospholipids may thus influence the activity of membrane-bound proteins via changes in membrane structure and function and may also affect neurotransmission directly or indirectly through changes in eicosanoids. More than 20 years ago, it was speculated that the fatty acid composition of both the maternal and neonatal diet may have profound effects on the nature of the lipid deposited in the brain and on the structure and function of cell membranes in the central nervous system (Widdowson et al. 1975). There is now clear evidence that the fatty acid composition of the newborn guinea-pig brain is influenced by the nature of the maternal dietary fat (Pavey \& Widdowson, 1980) and that the phospholipid composition of the cerebral cortex in babies is related to the infant's diet (Farquharson et al. 1992). Moreover, a study in rats demonstrated widespread and profound deleterious effects of maternal low-protein diets on brain development and fatty acid metabolism in the young (Marin et al. 1995); $n-3$ and $n-6$ polyunsaturated fatty acids within brain phosphatidylethanolamine were both reduced by the maternal lowprotein diet, whereas only the linoleic acid-derived products were similarly affected in the 
corresponding phosphatidylcholine fraction. Recent evidence on the relative importance of the $\mathrm{AA}$ : DHA ratio is discussed in the final section of this review.

\section{Undernutrition, behaviour and neurodevelopment}

Ethical considerations make it impossible to undertake controlled studies in human subjects on the impact of energy intake on behavioural development. However, assessment has been made of growth and academic achievement in children and the relation between height, weight, cognitive ability and neurodevelopmental level (Karp et al. 1992). Children with reduced somatic growth were likely to do poorly at school but the data did not show that undernutrition caused the learning failure. Rather, they suggested that environmental problems affecting the development of cognitive ability and nutrient intake precede both growth and learning failure. This study clearly demonstrates the difficulty in epidemiological studies of separating nutritional effects from other influential factors.

An indication of the extent to which food intake can alter different types of behaviour comes from an assessment of locomotor development in undernourished rats (Gramsbergen \& Westerga, 1992). Mothers were fed on $40 \%$ of normal amounts of rat chow from day 5 of gestation until weaning at $21 \mathrm{~d}$ postnatally. This resulted in delayed and prolonged developmental changes in locomotion of the pups, at least until $30 \mathrm{~d}$ after birth. Especially at lower speeds, walking was clumsy because of an unusually brisk onset, a slightly unsteady gait and non-fluent paw movements. Studies on underlying changes in neurodevelopment include an investigation of whether undernutrition and/or overnutrition in the neonatal rat has long-term effects on noradrenaline-producing neuronal pathways in specific brain regions (Seidler $e t$ al. 1990). Litter sizes were manipulated at birth to produce undernutrition (16-17 pups per litter) or overnutrition (5-6 pups per litter) and studies were conducted throughout the sucking period and during post-weaning nutritional rehabilitation. The outcome was striking: neonatal nutrition altered presynaptic and postsynaptic markers of noradrenergic function that remained abnormal even after nutritional rehabilitation.

Very few studies have been undertaken in human subjects on the underlying changes in neurodevelopment induced by undernutrition. However, the consequences of early postnatal nutrition on cortical dendritic development were investigated post-mortem in malnourished infants and well-nourished control infants who had died from pneumonia at 3-4 months of age (Cordero et al. 1993). Early postnatal undernutrition was found to affect the growth of pyramidal cells in the motor cortex, especially in relation to arborization and span of the basilar dendrites. It was concluded that malnutrition and social deprivation postnatally can induce changes in nervous tissue maturation which result in altered structure and probably function.

\section{Mechanisms mediating nutritional impairment of brain structure and function}

In relation to the detailed mechanisms by which early malnutrition may impair brain structure and function, evidence was reviewed which showed that: (1) developmental malnutrition induces central noradrenergic hyperactivity; (2) noradrenaline exerts a trophic role during brain development; and (3) pharmacological reduction of central noradrenergic hyperactivity prevents malnutrition-induced functional brain disturbances (Soto-Moyano et al. 1995). Another review on changing ideas and concerns in relation to malnutrition and the brain pointed out how conceptions had evolved considerably since the mid-1960s (Levitsky \& Strupp, 1995). At 
one time it was thought that malnutrition during certain sensitive periods would produce irreversible brain damage, possibly resulting in mental retardation and impairment in brain function. It now appears that most of the alterations in growth of various brain structures may eventually recover, to some extent, as a result of nutritional rehabilitation. However, it should be stressed that this is not the case in the hippocampus and cerebellum; in these regions, permanent alterations remain.

Neuropharmacological evidence has revealed long-lasting if not permanent changes in brain neural receptor function resulting from an early period of malnutrition. The types of behaviours and cognitive functions impaired by malnutrition may be related more to emotional responses to stressful events than to cognitive deficits per se. Indeed, a point highlighted by a number of studies during the last three decades is that important interactions can occur between early nutritional and behavioural experience. Studies aimed at defining the precise role of maternal deprivation may also be inadvertently investigating the role of undernutrition. Thus, neonatal experiences such as maternal deprivation and early weaning have been reported to influence the development of allergic encephalomyelitis in adult rats (Laban et al. 1995), while neonatal isolation enhances hippocampal response to tetanization at $30 \mathrm{~d}$ postnatally (Kehoe et al. 1995). However, in neither of these studies was nutrition or food intake mentioned.

\section{6 to 1997}

\section{Nutrition and cognitive function}

The role of nutrition in the development of normal cognition was the subject of a meeting subsequently published by the American Journal of Nutrition (Kretchmer et al. 1996). The potential role of trans fatty acids in fetal and infant neurodevelopment was also reviewed (Carlson et al. 1997). Another review highlighted the point that malnutrition during a sensitive period can affect development of the brain and retina, with long-term effects on cognition and visual function (Gordon, 1997). Continuing concern was also expressed with respect to malnutrition, poverty and intellectual development (Brown \& Pollitt, 1996) and the role of fetal and neonatal environment in brain development was also addressed (Nathanielsz, 1996).

Studies by Lucas's group continued and the hypothesis that fortified breast-milk, fed alone or with preterm formula, improves neurodevelopment and growth at 18 months of age was tested (Lucas et al. 1996). Short-term growth was improved but beneficial effects on long-term development remained unproven and it was concluded that future research should evaluate potential adverse consequences and explore optimal fortification strategies. A study in which breast-milk DHA was increased did not find any long-term effects of infant DHA status on indices of neurodevelopment (Gibson et al. 1997). However, DHA has been reported to improve visual acuity and mental development of small-for-gestational-age infants (Wasantwisut, 1997). The extent to which the AA: DHA ratio may influence cognitive behaviour is discussed in the final section of this present review. In general, evidence suggests that intensive nutritional care in the immediate postnatal period can have a direct impact on future health and development.

Insights into early malnutrition and child neurobehavioural development have also been gained from a study of children of diabetic mothers (Rizzo et al. 1997). Poorer maternal metabolic regulation was related to poorer child performance at 7-11 years, and this may have been mediated by the effects of disturbances in maternal metabolism on the fetal brain. 


\section{Prenatal protein malnutrition, hippocampal development and behaviour}

Studies on prenatal protein malnutrition and subsequent behavioural ability in maze-test paradigms revealed that it affects avoidance but not escape behaviour, and also influences exploratory behaviour (Almeida et al. 1996a,b). Results suggested that prenatal malnutrition leads to a reduction of anxiety and also that some responses are sex-specific. Moreover, sex differences have also been reported in relation to the role of neonatal isolation in alteration of hippocampal long-term potentiation (Bronzino et al. 1996b); an activation evoked, long-lasting enhancement of synaptic transmission that may represent a model for the cellular basis of memory formation. Early social behaviour is also altered by prenatal protein malnutrition, suggesting that this may play an important role in determining some of the later behavioural differences observed in adults (Almeida et al. 1996c).

Diet-induced alterations in the ontogeny of long-term potentiation have also been reported (Bronzino et al. 1996a). Most striking was the finding that significant impairments in establishment of long-term potentiation were found in prenatally malnourished rats at $90 \mathrm{~d}$ postnatally, implying that dietary rehabilitation starting at birth is an intervention incapable of ameliorating the effects of gestational insult. Having demonstrated that prenatal protein malnutrition significantly affects hippocampal plasticity, as measured by long-term potentiation, throughout development, attention was paid to the response of the hippocampal dentate granule cell population to two separate paradigms of tetanization of the medial perforant input pathway (Bronzino et al. 1997). The apparent inability of malnourished rats to transduce enhanced cellular activation into enhanced electrical discharge suggests that a preferential enhancement of inhibitory modulation of granule cell excitability mediated by $\gamma$-amino butyric acid may result from prenatal dietary insult. Such potentiation of inhibitory activity would significantly lower the probability of granule cell discharge. Prenatal protein deprivation also altered the postnatal pattern of granule cell neurogenesis in the rat hippocampal formation and the effect persisted despite nutritional rehabilitation from birth (Debassio et al. 1996).

A study on CA1 hippocampal pyramidal cells was the third in a series of morphometric studies on the effect of prenatal protein restriction on key neurones in the hippocampal trisynaptic circuit (Cintra et al. 1997a). When compared with their previous studies on the dentate granule cell and the CA3 pyramidal cell, it was found that a low-protein diet affects all of these neurones, with the most marked effect being on the predominantly postnatally generated dentate granule cells. The mossy fibre plexus, which represents the dentate gyrus granule cell axonal projection to areas CA4 and CA3 of the hippocampal formation, was also investigated (Cintra et al. 1997b). Although there was no effect of prenatal protein deprivation on the anatomical distribution of the plexus, there were age-dependent effects on its postnatal development: significant deficits in the total rostro-caudal extent and volume of the plexus occurred.

The effects of age and prenatal protein malnutrition on the concentration of monoamine neurotransmitters and their metabolites and precursors in the hippocampal formation, striatum, brainstem and cerebral cortex were also investigated in rats at 1, 15, 30, 45, 90 and $220 \mathrm{~d}$ (Chen et al. 1997). Monoamine transmitter content varied dynamically throughout postnatal life. However, in most instances the changes seemed to counteract the insult from prenatal protein malnutrition after postnatal rehabilitation. Taken together, these studies indicate profound effects of prenatal protein malnutrition on hippocampal development and behaviour. Similarly detailed investigations have yet to be undertaken on the impact of prenatal undernutrition on neurodevelopment. 
Nutrition, neurodevelopment and schizophrenia

Evidence suggests that schizophrenia may in some cases be a neurodevelopmental disorder, resulting in part from the effects of prenatal exposure to certain risk factors including malnutrition, hypoxia, viruses or drugs. Four lines of evidence support prenatal nutritional deficiencies as a plausible set of risk factors for schizophrenia (Brown et al. 1996): their effects are not incompatible with the epidemiology of the disease, they have adverse effects on brain development, general malnutrition results in neuropathological anomalies of brain regions implicated in the disease, and prenatal malnutrition affects maternal systems critical to the developing fetal nervous system.

Compared with the general population, a consistent finding in schizophrenia is a significant surplus of births in the winter and spring months (Franzek \& Beckmann, 1996). Exogenous harmful effects predominant during the cold season may affect the developing immature fetal brain and neuropathological and epidemiological studies point to the second trimester as a critical period for fetal brain maturation. It was suggested that schizophrenia is not a disease entity but consists of aetiologically distinct subgroups in which the influence of genes and/or environment has to be weighted differently. In sporadic forms of the disease, exogenous agents may be of major importance, while in fetuses at high genetic risk neurodevelopment may already be disturbed and additional exogenous agents can cause abortions, still-births and sudden infant deaths. It appears, therefore, that interactions between genetic and environmental factors are important in mediating the development of schizophrenia and evidence implicates the prefrontal cortex as the site of developmental dysfunction (Glantz \& Lewis, 1997). Undoubtedly there is considerable difficulty in distinguishing between genetically determined and environmentally determined neurointegrative deficits (Marcus et al. 1981). The most likely probability is that there are critical interactions between genetic and environmental factors such as nutrition and this is discussed in the final section.

\section{Current and future perspectives}

\section{Low birth weight and later cognitive performance}

Interest in programming by early nutrition continues and it is now well-recognized that events during critical or sensitive periods of development may program long-term structure and function. After 16 years of randomized intervention studies of early nutrition in low birthweight infants, it can be concluded that human subjects, like other animals, have sensitive windows for nutrition in terms of later outcomes: for example, perinatal diet influences neurodevelopment into mid-childhood (Lucas, 1998).

Possible mechanisms by which early nutrition affects later outcome include adaptive changes in gene expression, preferential clonal selection of adapted cells, and differential proliferation of specific cell types. Details of mechanisms which may be involved in these responses are discussed throughout this present review. In addition, a number of key phases in neurodevelopment have yet to be investigated in the present context and should be the subject of future study. Widespread cell migrations occur during brain development (Hatten, 1999) and abnormal neuronal migration and impaired cognitive function have been linked to prenatal exposure to radiation (Schull \& Otake, 1999; Sun et al. 1999). One can therefore postulate, for example, that during hippocampal development not only cell proliferation and differentiation but also neuronal migration may be modified by prenatal nutrition. 
In relation to intrauterine growth retarded/small-for-gestational age infants born either before term or at term, the probability is that effects on cognitive function will be related to the age at which the malnutrition and/or hypoxia occurs. In human subjects, for example, most neurones are formed before 20 weeks of gestation. Recent evidence of some neuronal progenitor cells and neurogenesis in adult human hippocampus (Eriksson et al. 1998) does, however, suggest a mechanism by which optimal nutrition later in life might ameliorate the effects of adverse early development. Although it is generally thought that neuronal loss is irreversible in the adult brain, this study clearly showed that the human hippocampus retains its ability to generate neurones throughout life.

\section{Functional consequences of prenatal malnutrition}

Following earlier investigations which showed that prenatal protein malnutrition alters development of the hippocampal formation in rats, assessment was made of possible functional consequences for the physiology of two types of principal neurones in adult rat hippocampus (Rushmore et al. 1998). No alterations were found in a range of electrophysiological properties measured with whole-cell current clamp recordings and there were no effects on extracellular measures of glutamate synaptic transmission in either dentate granule cells or CA1 pyramidal cells.

The specific effects of choline on developing rat hippocampus have also been assessed because it is known to influence long-term memory in concert with changes in spatial organization and morphology of neurones in the septum (Albright et al. 1998). Immunohistochemical localization of the growth-related proteins transforming growth factor $\beta$ type 1 (TGF $\beta 1$ ) and growth-associated protein-43 (GAP-43), the cytoskeletal proteins vimentin and microtubule-associated protein-1 (MAP-1), and the neuronal cell marker neurone-specific enolase (EC 4.2.1.11) was determined in fetal brain from dams fed on a choline-supplemented or choline-deficient diet from 12 until 18 days of gestation. Data suggested that choline availability modulates differentiation of specific regions of the developing hippocampus.

\section{Specific dietary components and brain development}

That specific nutrients can affect neurotransmission and neurodevelopment is well established, and investigations on the influence of specific components of the neonatal diet on behavioural development were reviewed recently (Wauben \& Wainwright, 1999). Potential mechanisms mediating these effects were also discussed. Not only can the energy and nutrient content of the diet alter the overall processes of growth and differentiation, but specific nutrients may be involved presynaptically in the synthesis, release or metabolism of neurotransmitters. Moreover, they may also influence the sensitivity or concentration of postsynaptic receptors and alter signalling pathways via changes in membrane structure and function.

Dietary long-chain polyunsaturated fatty acids are important for the neurodevelopment of human infants, and especially those born preterm or with low birth weight (Gibson \& Makrides, 1998; Guesry, 1998; Woltil et al. 1998). Preterm infants may be born with deficits of both AA and DHA and indeed it was suggested recently that the essential fatty acid content of feeds for these infants is formulated incorrectly (Crawford et al. 1998). An assessment of the roles of dietary AA and DHA in behavioural development highlighted the importance of the relative amounts of dietary $n-3$ and $n-6$ fatty acids to the developing brain, and attention was drawn to the relatively few animal studies on the influence of dietary essential fatty acids on 
behavioural outcome (Wauben \& Wainwright, 1999). A recent study has, however, been undertaken in artificially-reared rat pups, a model which avoids manipulation of maternal diet and hence of potential confounding factors such as maternal physiology and behaviour (Wainwright et al. 1999). Although variation in the AA : DHA ratio did not affect forebrain and working-memory performance, it is possible that more subtle behavioural variations may have occurred. Moreover, the likelihood is that changes in brain biochemistry, such as phospholipid composition, provide little indication of changes at the neurophysiological level. Thus, the proposed function of AA as a retrograde transmitter involved in synaptic plasticity (Bliss \& Collingridge, 1993) may be modified by specific components of the diet.

Continuing interest in the role of maternal fatty acid intake on development of the fetal brain is evident. A protective effect of fish consumption and a detrimental effect of meat intake in relation to development of cerebral palsy suggests a potential role for fish-derived $n$ - 3 fatty acids (Petridou et al. 1998). By contrast, a delay in appearance of the auditory startle reflex and longer auditory brainstem conduction times in rat pups from dams fed on fish-oil supplemented compared with corn-oil supplemented diets suggested negative effects on myelination of the auditory brainstem pathway with higher levels of $n-3$ compared with $n-6$ fatty acids (Saste $e t a l$. 1998).

\section{Neurodevelopment and later disease}

A recent study on the epidemiology of schizophrenia suggests that although a family history of the disease is a high risk factor, environmental factors such as the place and season of birth account for many more cases on a population basis (Mortensen et al. 1999). Future research in this field should involve identification of susceptibility genes and their role during the epidemiologically defined critical period.

Alzheimer's disease is characterized by progressive loss of short-term memory followed by cognitive decline. Recent studies have shown that synaptic loss in the cortex is the major correlate of this decline and that there is an especially marked effect on synaptophysin and synaptobrevin, the presynaptic proteins localized mainly in transmitter-containing synaptic vesicles (Shimohama et al. 1997). Synaptic abnormalities in the hippocampus correlate with the severity of neuropathology and memory deficit in people with Alzheimer's disease; there is a loss in synaptophysin and this defect may predate neuropsychological evidence for cognitive impairment (Sze et al. 1997). Although there is no evidence linking environmental factors with development of Alzheimer's disease, it remains to be established whether early nutrition can affect its developmental outcome.

\section{Diet, drug and hormone interventions for reversing or slowing the effects of ageing}

An assessment of the ageing of the $N$-methyl-D-aspartate (NMDA) receptor complex indicated that a number of drug and diet interventions may reverse or slow the effects of ageing (Magnusson, 1998). The NMDA receptors, which mediate fast excitatory transmission by glutamate, are present at high density in the cerebral cortex and hippocampus and play an important role in learning and memory. Moreover, there is an association between lower densities of NMDA receptor binding and poor memory performance in aged animals. Development of treatments aimed at preventing or reversing the effects of ageing on the NMDA receptor could thus help in preventing the memory declines that are associated with ageing. Studies in mice at 3 and 24 months old indicate that prolonged physical training can modify the 
age-related decrease in the synaptically localized proteins synaptophysin and GAP-43, as assessed by immunostaining and image analysis, in the CA1, CA3 areas and dentate gyrus of the hippocampal formation (Chen et al. 1998). It was suggested that this increased expression might be associated with anatomical sprouting and synaptogenesis. No mention was made of the possibility that the results could be related in part to differences in energy intake and this aspect remains to be investigated. In keeping with the well-known effects of life-long dietary restriction in delaying the onset and progression of many age-related physiological deficits, a $50 \%$ reduction in energy intake has been found to attenuate the age-related increase in hippocampal glial fibrillary acidic protein mRNA (Major et al. 1997). This intermediate filament protein is specifically expressed in astrocytic glial cells.

Studies in aged, 26-month-old male mice and rats strongly suggest that energy restriction exerts many of its beneficial effects on modulating disease and longevity via the hypothalamicpituitary-adrenal axis (Duffy et al. 1997). A reduction in food intake increases plasma glucocorticoid levels and alters the patterns of pulsatile, circadian and ultradian glucocorticoid release, whereas overfeeding results in lower glucocorticoid levels (see Katsumata et al. 1999). Their receptors are present in several brain areas and are most abundant in the hippocampus where they play an essential role in glucocorticoid feedback inhibition. The precise role of glucocorticoids in neurodevelopment and long-term outcome has yet to be established. There is a fine balance between the beneficial and harmful effects of these hormones, which is related in part to stage of development and the magnitude and duration of any changes (Fowden $e t$ al. 1998). Intrauterine programming of the hypothalamic-pituitary-adrenal axis has been implicated in the link between low birth-weight and later disease (Phillips et al. 1998) and elevated basal cortisol levels may cause hippocampal damage and hippocampus-dependent learning and memory deficits in elderly human subjects (Lupien et al. 1998). Clearly, an important area for future investigation is to determine the extent to which diet can influence glucocorticoid receptors in the hippocampus during prenatal, postnatal and adult life.

\section{Regulation of synaptic plasticity}

Presynaptic and postsynaptic membranes. The mechanism whereby synapses can change their effectiveness as a result of the previous pattern of activity is termed synaptic plasticity. Activation of glucocorticoid receptors may underlie some forms of synaptic plasticity (Xu et al. 1998) and modulate the postsynaptic but not presynaptic effects of serotonin induced suppression of synaptic excitability in the CA1 hippocampal area (Hesen et al. 1998). A recent review highlighted the complexity of molecular mechanisms underlying structural and functional changes at the postsynaptic membrane during synaptic plasticity (Wheal et al. 1998). Specifically, the synaptic plasticity that follows neurodegeneration in the kainic acid lesioned hippocampus was addressed, and attention was drawn to "the collections of cogs in the underlying molecular machinery'. These include the neural recognition molecules and their role in synaptic plasticity in the adult nervous system. Thus, neural cell adhesion molecules, cadherins and amyloid precursor protein are involved at the morphogenetic level in synaptic changes and in signal transduction effects. Moreover, the LDL receptor family of genes and their ligands play pivotal roles in brain development and in regulating growth and remodelling of neurones and have a role in maintenance of cognitive function and as a risk factor in Alzheimer's disease. The molecular mechanisms responsible for the clustering and maintenance of transmitter receptors at postsynaptic sites are gradually being elucidated. Postsynaptic densities from excitatory synapses have yielded many cytoskeletal proteins including actin, spectrin, tubulin, MAP and $\mathrm{Ca}^{2+} /$ calmodulin-dependent protein kinase II (EC 2.7.1.123) Recently, a new family of proteins, the membrane-associated guanylate kinases has emerged. 
They are thought to play a role in synaptic plasticity mediated by NO. Although only a relatively few key players have been identified, it is clear that there are a number of potentially significant molecules which need to be investigated with respect to the nutritional and developmental regulation of both the presynaptic and postsynaptic membranes.

Growth factors and hormones. Another potentially important area for future investigation is suggested by a recent study of the presynaptic modulation of synaptic transmission and plasticity induced by brain-derived neurotrophic factor (BDNF) in the developing hippocampus (Gottschalk et al. 1998). In addition to the regulation of neuronal survival and differentiation, neurotrophins may play a role in synapse development and plasticity. Application of BDNF promotes long-term potientiation in CA1 synapses of neonatal hippocampus, which otherwise exhibit only short-term potentiation. This is attributable at least in part to an attenuation of the synaptic fatigue induced by high-frequency stimulation, which could be mediated by an attenuation of synaptic vesicle depletion from presynaptic terminals and/or reduction in the densensitization of postsynaptic receptors. This study has provided evidence supporting a presynaptic effect of BDNF and the preferential potentiation of highly active synapses by BDNF may have implications for the mechanisms of synaptic plasticity. Early maternal separation has been found to increase nerve growth factor (NGF) expression in the dentate gyrus and hilus of the developing rat hippocampus (Cirulli et al. 1998). Whether this growth factor, which is involved in growth and differentiation of central cholinergic neurones, is also influenced by early malnutrition is not known. The role of BDNF has also been assessed in relation to chronic restraint stress, which produces an atrophy of apical dendrites in the CA3 region of the hippocampus, which in turn is blocked by the novel antidepressant tianeptine (Kuroda \& McEwen, 1998). Assessment of mRNA expression of BDNF, neurotrophin-3, basic fibroblast growth factor and GAP-43 indicated that they are not likely to be related directly to the chronic stress-induced dendritic atrophy or its prevention by tianeptine.

Possible interactions between neurotrophins and nutritionally-induced changes in thyroid hormones (Dauncey, 1990; Morovat \& Dauncey, 1995) may be relevant in the present context and need to be investigated. The super-family of nuclear steroid/thyroid hormone receptors act as transcriptional regulators and have the ability to regulate the expression of numerous target genes. Nutrition in turn has been shown to regulate the tissue-specific expression of thyroid hormone receptor $\alpha$ isoforms (White \& Dauncey, 1998, 1999). Evidence that thyroid hormone receptor $\alpha 1$ isoform expression induces expression of the TrkB neurotrophin receptor in neuroblastoma cells (Pastor et al. 1994) suggests that thyroid hormone receptor isoforms may have the ability to influence neurotrophin signalling during early development. Moreover, within $2 \mathrm{~h}$, BDNF but not nerve growth factor upregulates synaptophysin, tau and c-FOS in cerebellar granular cells, correlating with expression of TrkB; there is however no effect on GAP-43 (Coffey et al. 1997). These studies, together with those on glucocorticoids mentioned previously, highlight the potentially significant impact which hormones acting as nutritional signals may have on neurodevelopment. Recent advances in understanding of the mechanisms by which sex steroids interact with neurotrophin signalling and influence brain development and function (Bicknell, 1998) also highlight the need to consider sex-related differences in any future studies on nutrition and neurodevelopment and suggest additional strategies for neuroprotective therapy.

Synaptic development and function. A number of other important markers of synaptic development and function have yet to be investigated in relation to long-term programming by early nutrition. These include the synaptic vesicle proteins synaptophysin, synaptoporin, synapsin, Rab3a and synaptotagmin, the presynaptic plasma membrane proteins syntaxin and synaptosomal-associate protein of $25 \mathrm{kD}$, and the post-synaptic protein neurogranin (Davidsson \& Blennow, 1998; Ferrer et al. 1998; Grosse et al. 1998; Hansen et al. 1998; Heffernan et al. 
1998; Young et al. 1998). Moreover, the regional expression as well as synaptic localizations of the glutamate receptor subunit GluR1 are developmentally regulated and this may be relevant to the differing responsiveness of perinatal and adult brain to exogenous stimuli (Martin et al. 1998). Investigations at the level of diet and gene expression are currently limited and this would appear to be an important area for exploration in future studies. Recent studies on quantitative analysis of mRNA expression of neurone-specific, growth-associated genes in rat primary cultured hippocampal neurones by competitive reverse transcriptase-polymerase chain reaction are of particular relevance (Wang \& Dow, 1998). The expression and regulation of the neurone-specific growth-associated genes T $\alpha 1 \alpha$-tubulin, MAP-2 and GAP-43, all of which have been proposed as putative markers of neurite outgrowth during differentiation and regeneration of cultured neurones, were quantified. This technique, in combination with morphological evaluation, could be a useful tool for evaluating neurite outgrowth under conditions of altered nutritional status.

\section{Concluding remarks}

Considerable evidence, from studies in human subjects and other animals, demonstrates that both prenatal and early postnatal nutrition influence later outcome in relation to brain structure and function, and cognitive performance. Effects are dependent on the type, timing and amplitude of the nutritional manipulation. In human subjects, attention has focused on the diet of preterm infants, especially in relation to specific components of the diet including long-chain fatty acids. However, despite the well-recognized effects of level of energy intake on neurodevelopment, for ethical reasons it has been impossible to study this nutritional aspect in humans using controlled randomized studies.

In relation to hippocampal development, much attention has focused on the influence of prenatal maternal protein intake in the rat on long-term potentiation. Considerably less attention has been paid to level of energy intake during prenatal and postnatal development and to the molecular events occurring at the synapse by which early nutrition induces long-term changes in neurodevelopment. Nutritionally-induced changes in hormones and their receptors within specific brain regions may play an important role in mediating the effects of diet on later development and would merit detailed investigation. In view of differences between animal strains in relation to environmental stimuli and cognitive function, the role of diet-gene interactions should also be considered as a potentially critical factor for future investigation. In conclusion, there is considerable scope for investigation of molecular mechanisms underlying nutritionally-induced impairment of neurodevelopment and long-term outcome in relation to cognitive function and disease in adult life. Detailed studies in model systems will provide the understanding needed for optimizing preventative and ameliorative strategies in humans during prenatal and postnatal development.

\section{Acknowledgement}

The Babraham Institute is supported by the Biotechnology and Biological Sciences Research Council. 


\section{References}

Albright CD, Tsai AY, Mar MH \& Zeisel SH (1998) Choline availability modulates the expression of TGF $\beta 1$ and cytoskeletal proteins in the hippocampus of developing rat brain. Neurochemical Research 23, 751-758.

Almeida SS, Tonkiss J \& Galler JR (1996a) Prenatal protein malnutrition affects avoidance but not escape behavior in the elevated T-maze test. Physiology and Behavior 60, 191-195.

Almeida SS, Tonkiss J \& Galler JR (1996b) Prenatal protein malnutrition affects exploratory behavior of female rats in the elevated plus-maze test. Physiology and Behavior 60, 675-680.

Almeida SS, Tonkiss J \& Galler JR (1996c) Prenatal protein malnutrition affects the social interactions of juvenile rats. Physiology and Behavior 60, 197-201.

Atallah MT, Barbeau IS \& Pellett PL (1977) Metabolic and development changes in growing rats born to dams restricted in protein and/or energy intake. Journal of Nutrition 107, 650-655.

Austin KB, Bronzino J \& Morgane PJ (1986) Prenatal protein malnutrition affects synaptic potentiation in the dentate gyrus of rats in adulthood. Brain Research 394, 267-273.

Austin-Lafrance RJ, Morgane PJ \& Bronzino JD (1991) Prenatal protein malnutrition and hippocampal function: rapid kindling. Brain Research Bulletin 27, 815-818.

Barker DJ (1995) The Wellcome Foundation Lecture, 1994. The fetal origins of adult disease. Proceedings of the Royal Society of London. Series B: Biological Sciences 262, 37-43.

Bedi KS, Massey RF \& Smart JL (1989) Neuronal and synaptic measurements in the visual cortex of adult rats after undernutrition during normal or artificial rearing. Journal of Comparative Neurology 289, 89-98.

Bedi KS, Thomas YM, Davies CA \& Dobbing J (1980) Synapse-to-neuron ratios of the frontal and cerebellar cortex of 30-day-old and adult rats undernourished during early postnatal life. Journal of Comparative Neurology 193, $49-56$.

Bicknell RJ (1998) Sex-steroid actions on neurotransmission. Current Opinion in Neurology 11, 667-671.

Bliss TV \& Collingridge GL (1993) A synaptic model of memory: long-term potentiation in the hippocampus. Nature 361, $31-39$.

Bronzino JD, Austin K, Siok CJ, Cordova C \& Morgane PJ (1983) Spectral analysis of neocortical and hippocampal EEG in the protein malnourished rat. Electroencephalography and Clinical Neurophysiology 55, 699-709.

Bronzino JD, Austin-LaFrance RJ, Mokler D \& Morgane PJ (1997) Effects of prenatal protein malnutrition on hippocampal long-term potentiation in freely moving rats. Experimental Neurology 148, 317-323.

Bronzino JD, Austin-LaFrance RJ \& Morgane PJ (1990) Effects of prenatal protein malnutrition on perforant path kindling in the rat. Brain Research 515, 45-50.

Bronzino JD, Austin-LaFrance RJ, Morgane PJ \& Galler JR (1991a) Effects of prenatal protein malnutrition on kindling-induced alterations in dentate granule cell excitability. I. Synaptic transmission measures. Experimental Neurology 112, 206-215

Bronzino JD, Austin-LaFrance RJ, Morgane PJ \& Galler JR (1991b) Effects of prenatal protein malnutrition on kindling-induced alterations in dentate granule cell excitability. II. Paired-pulse measures. Experimental Neurology 112, 216-223.

Bronzino JD, Austin-LaFrance RJ, Morgane PJ \& Galler JR (1996a) Diet-induced alterations in the ontogeny of longterm potentiation. Hippocampus 6, 109-117.

Bronzino JD, Austin-LaFrance RJ, Siok CJ \& Morgane PJ (1986) Effect of protein malnutrition on hippocampal kindling: electrographic and behavioral measures. Brain Research 384, 348-354.

Bronzino JD, Kehoe P, Austin-LaFrance RJ, Rushmore RJ \& Kurdian J (1996b) Neonatal isolation alters LTP in freely moving juvenile rats: sex differences. Brain Research Bulletin 41, 175-183.

Bronzino JD, Stisser P, Forbes WB, Tracy C, Resnick O \& Morgane PJ (1980) Power spectral analysis of the EEG following protein malnutrition. Brain Research Bulletin 5, 51-60.

Brown AS, Susser ES, Butler PD, Richardson Andrews R, Kaufmann CA \& Gorman JM (1996) Neurobiological plausibility of prenatal nutritional deprivation as a risk factor for schizophrenia. Journal of Nervous and Mental Disease 184, 71-85.

Brown JL \& Pollitt E (1996) Malnutrition, poverty and intellectual development. Scientific American 274, 38 -43.

Carlson SE, Clandinin MT, Cook HW, Emken EA \& Filer LJ Jr (1997) Trans fatty acids: infant and fetal development. American Journal of Clinical Nutrition 66, 715S-736S.

Carughi A, Carpenter KJ \& Diamond MC (1989) Effect of environmental enrichment during nutritional rehabilitation on body growth, blood parameters and cerebral cortical development of rats. Journal of Nutrition 119, $2005-2016$.

Chen JC, Turiak G, Galler J \& Volicer L (1997) Postnatal changes of brain monoamine levels in prenatally malnourished and control rats. International Journal of Developmental Neuroscience 15, 257-263.

Chen YC, Chen QS, Lei JL \& Wang SL (1998) Physical training modifies the age-related decrease of GAP-43 and synaptophysin in the hippocampal formation in C57BL/6J mouse. Brain Research 806, 238-245.

Cintra L, Aguilar A, Granados L, Galvan A, Kemper T, DeBassio W, Galler J, Morgane P, Duran P \& Diaz-Cintra S (1997a) Effects of prenatal protein malnutrition on hippocampal CA1 pyramidal cells in rats of four age groups. Hippocampus 7, 192-203. 
Cintra L, Granados L, Aguilar A, Kemper T, DeBassio W, Galler J, Morgane P, Duran P \& Diaz-Cintra S (1997b) Effects of prenatal protein malnutrition on mossy fibers of the hippocampal formation in rats of four age groups. Hippocampus 7, 184-191.

Cirulli F, Micera A, Alleva E \& Aloe L (1998) Early maternal separation increases NGF expression in the developing rat hippocampus. Pharmacology, Biochemistry and Behavior 59, 853-858.

Coffey ET, Akerman KE \& Courtney MJ (1997) Brain derived neurotrophic factor induces a rapid upregulation of synaptophysin and tau proteins via the neurotrophin receptor TrkB in rat cerebellar granule cells. Neuroscience Letters 227, 177-180.

Cordero ME, D’Acuna E, Benveniste S, Prado R, Nunez JA \& Colombo M (1993) Dendritic development in neocortex of infants with early postnatal life undernutrition. Pediatric Neurology 9, 457-464.

Crawford MA, Costeloe K, Ghebremeskel K \& Phylactos A (1998) The inadequacy of the essential fatty acid content of present preterm feeds. European Journal of Pediatrics 157, S23-S27.

Crawford MA, Doyle W, Drury P, Lennon A, Costeloe K \& Leighfield M (1989) n-6 and n-3 fatty acids during early human development. Journal of Internal Medicine, Suppl., 225, 159-169.

Crawford MA, Doyle W, Leaf A, Leighfield M, Ghebremeskel K \& Phylactos A (1993) Nutrition and neurodevelopmental disorders. Nutrition and Health 9, 81-97.

Dauncey MJ (1990) Thyroid hormones and thermogenesis. Proceedings of the Nutrition Society 49, 203-215.

Dauncey MJ (1997) From early nutrition and later development ... to underlying mechanisms and optimal health. British Journal of Nutrition 78, S113-S123.

Davidsson P \& Blennow K (1998) Neurochemical dissection of synaptic pathology in Alzheimer's disease. International Psychogeriatrics 10, 11-23.

de Andraca I \& Uauy R (1995) Breastfeeding for optimal mental development. The alpha and the omega in human milk. World Review of Nutrition and Dietetics 78, 1-27.

Debassio WA, Kemper TL, Tonkiss J \& Galler JR (1996) Effect of prenatal protein deprivation on postnatal granule cell generation in the hippocampal dentate gyrus. Brain Research Bulletin 41, 379-383.

Diaz-Cintra S, Garcia-Ruiz M, Corkidi G \& Cintra L (1994) Effects of prenatal malnutrition and postnatal nutritional rehabilitation on CA3 hippocampal pyramidal cells in rats of four ages. Brain Research 662, 117-126.

Dobbing J (1990) Boyd Orr memorial lecture. Early nutrition and later achievement. Proceedings of the Nutrition Society 49, 103-118.

Duffy PH, Leakey JE, Pipkin JL, Turturro A \& Hart RW (1997) The physiologic, neurologic, and behavioral effects of caloric restriction related to aging, disease, and environmental factors. Environmental Research 73, 242-248.

Eriksson PS, Perfilieva E, Bjork-Eriksson T, Alborn AM, Nordborg C, Peterson DA \& Gage FH (1998) Neurogenesis in the adult human hippocampus. Nature Medicine 4, 1313-1317.

Farquharson J, Cockburn F, Patrick WA, Jamieson EC \& Logan RW (1992) Infant cerebral cortex phospholipid fattyacid composition and diet. Lancet 340, 810-813.

Fernald LC \& Grantham-McGregor SM (1998) Stress response in school-age children who have been growth retarded since early childhood. American Journal of Clinical Nutrition 68, 691-698.

Ferrer I, Marti E, Tortosa A \& Blasi J (1998) Dystrophic neurites of senile plaques are defective in proteins involved in exocytosis and neurotransmission. Journal of Neuropathology and Experimental Neurology 57, 218-225.

Forbes WB, Resnick O, Stern WC, Bronzino JD \& Morgane PJ (1975) The effect of chronic protein malnutrition on trans-callosal evoked responses in the rat. Developmental Psychobiology 8, 503-509.

Fowden AL, Li J \& Forhead AJ (1998) Glucocorticoids and the preparation for life after birth: are there long-term consequences of the life insurance? Proceedings of the Nutrition Society 57, 113-122.

Franklin KBJ \& Paxinos G (1997) The Mouse Brain in Stereotaxic Coordinates. San Diego, CA: Academic Press.

Franzek E \& Beckmann H (1996) Gene-environment interaction in schizophrenia: season-of-birth effect reveals etiologically different subgroups. Psychopathology 29, 14-26.

Gibson RA \& Makrides M (1998) The role of long chain polyunsaturated fatty acids (LCPUFA) in neonatal nutrition. Acta Paediatrica 87, 1017-1022.

Gibson RA, Neumann MA \& Makrides M (1997) Effect of increasing breast milk docosahexaenoic acid on plasma and erythrocyte phospholipid fatty acids and neural indices of exclusively breast fed infants. European Journal of Clinical Nutrition 51, 578-584.

Glantz LA \& Lewis DA (1997) Reduction of synaptophysin immunoreactivity in the prefrontal cortex of subjects with schizophrenia. Regional and diagnostic specificity. Archives of General Psychiatry 54, 943-952.

Gordon N (1997) Nutrition and cognitive function. Brain and Development 19, 165-170.

Gottschalk W, Pozzo-Miller LD, Figurov A \& Lu B (1998) Presynaptic modulation of synaptic transmission and plasticity by brain-derived neurotrophic factor in the developing hippocampus. Journal of Neuroscience 18, 68306839.

Gramsbergen A \& Westerga J (1992) Locomotor development in undernourished rats. Behavioural Brain Research 48 , $57-64$.

Grantham-McGregor S, Schofield W \& Powell C (1987) Development of severely malnourished children who received psychosocial stimulation: six-year follow-up. Pediatrics 79, 247-254.

Grosse G, Tapp R, Wartenberg M, Sauer H, Fox PA, Grosse J, Gratzl M \& Bergmann M (1998) Prenatal hippocampal granule cells in primary cell culture form mossy fiber boutons at pyramidal cell dendrites. Journal of Neuroscience Research 51, 602-611. 
Guesry P (1998) The role of nutrition in brain development. Preventive Medicine 27, 189-194.

Hansen LA, Daniel SE, Wilcock GK \& Love S (1998) Frontal cortical synaptophysin in Lewy body diseases: relation to Alzheimer's disease and dementia. Journal of Neurology, Neurosurgery and Psychiatry 64, 653-656.

Hatten ME (1999) Central nervous system neuronal migration. Annual Review of Neuroscience 22, 511-539.

Hay WW Jr (1994) Nutritional requirements of extremely low birthweight infants. Acta Paediatrica, Suppl., 402, 94-99.

Heffernan JM, Eastwood SL, Nagy Z, Sanders MW, McDonald B \& Harrison PJ (1998) Temporal cortex synaptophysin mRNA is reduced in Alzheimer's disease and is negatively correlated with the severity of dementia. Experimental Neurology 150, 235-239.

Hesen W, Karten YJ, van de Witte SV \& Joels M (1998) Serotonin and carbachol induced suppression of synaptic excitability in rat CA1 hippocampal area: effects of corticosteroid receptor activation. Journal of Neuroendocrinology 10, 9-19.

Hoet JJ \& Hanson MA (1999) Intrauterine nutrition: its importance during critical periods for cardiovascular and endocrine development. Journal of Physiology (London) 514, 617-627.

Innis SM (1994) The 1993 Borden Award Lecture. Fatty acid requirements of the newborn. Canadian Journal of Physiology and Pharmacology 72, 1483-1492.

Ishimura K, Takeuchi Y, Fujiwara K, Yoshioka H, Sawada T \& Kusunoki T (1989) Effects of undernutrition on the serotonin neuron system in the developing brain: an immunohistochemical study. Brain Research. Developmental Brain Research 50, 225-231.

Kandel ER \& Sahwartz JH (editors) (1985) Principles of Neural Science, 2nd ed. New York: Elsevier.

Karp R, Martin R, Sewell T, Manni J \& Heller A (1992) Growth and academic achievement in inner-city kindergarten children. The relationship of height, weight, cognitive ability, and neurodevelopmental level. Clinical Pediatrics (Philadelphia) 31, 336-340.

Katsumata M, Burton KA, Li J \& Dauncey MJ (1999) Suboptimal energy balance selectively up-regulates muscle GLUT gene expression but reduces insulin-dependent glucose uptake during postnatal development. FASEB Journal 13, $1405-1413$

Kehoe P, Hoffman JH, Austin-LaFrance RJ \& Bronzino JD (1995) Neonatal isolation enhances hippocampal dentate response to tetanization in freely moving juvenile male rats. Experimental Neurology 136, 89-97.

Kolb B \& Gibb R (1990) Anatomical correlates of behavioural change after neonatal prefrontal lesions in rats. Progress in Brain Research 85, 241-255.

Kolb B \& Whishaw IQ (1989) Plasticity in the neocortex: mechanisms underlying recovery from early brain damage. Progress in Neurobiology 32, 235-276.

Kretchmer N, Beard JL \& Carlson S (1996) The role of nutrition in the development of normal cognition. American Journal of Clinical Nutrition 63, 997S-1001S

Krigman MR \& Hogan EL (1976) Undernutrition in the developing rat: effect upon myelination. Brain Research 107, $239-255$.

Kuroda Y \& McEwen BS (1998) Effect of chronic restraint stress and tianeptine on growth factors, growth-associated protein-43 and microtubule-associated protein 2 mRNA expression in the rat hippocampus. Brain Research. Molecular Brain Research 59, 35-39.

Laban O, Markovic BM, Dimitrijevic M \& Jankovic BD (1995) Maternal deprivation and early weaning modulate experimental allergic encephalomyelitis in the rat. Brain, Behavior, and Immunity 9, 9-19.

Lai M \& Lewis PD (1980) Effects of undernutrition on myelination in rat corpus callosum. Journal of Comparative Neurology 193, 973-982.

Lai M, Lewis PD \& Patel AJ (1980) Effects of undernutrition on gliogenesis and glial maturation in rat corpus callosum. Journal of Comparative Neurology 193, 965-972.

Lanting CI \& Boersma ER (1996) Lipids in infant nutrition and their impact on later development. Current Opinion in Lipidology 7, 43-47.

Lanting CI, Fidler V, Huisman M, Touwen BC \& Boersma ER (1994) Neurological differences between 9-year-old children fed breast-milk or formula-milk as babies. Lancet 344, 1319-1322.

Levitsky DA \& Strupp BJ (1995) Malnutrition and the brain: changing concepts, changing concerns. Journal of Nutrition 125, 2212S-2220S.

Lucas A (1994) Role of nutritional programming in determining adult morbidity. Archives of Disease in Childhood 71, $288-290$.

Lucas A (1998) Programming by early nutrition: an experimental approach. Journal of Nutrition 128, 401S-406S.

Lucas A, Fewtrell MS, Morley R, Lucas PJ, Baker BA, Lister G \& Bishop NJ (1996) Randomized outcome trial of human milk fortification and developmental outcome in preterm infants. American Journal of Clinical Nutrition 64, $142-151$.

Lucas A, Morley R, Cole TJ, Gore SM, Davis JA, Bamford MF \& Dossetor JF (1989) Early diet in preterm babies and developmental status in infancy. Archives of Disease in Childhood 64, 1570-1578.

Lucas A, Morley R, Cole TJ, Lister G \& Leeson-Payne C (1992) Breast milk and subsequent intelligence quotient in children born preterm. Lancet 339, 261-264.

Lupien SJ, de Leon M, de Santi S, Convit A, Tarshish C, Nair NP, Thakur M, McEwen BS, Hauger RL \& Meaney MJ (1998) Cortisol levels during human aging predict hippocampal atrophy and memory deficits. Nature Neuroscience $\mathbf{1}$, $69-73$. 
Magnusson KR (1998) The aging of the NMDA receptor complex. Frontiers in Biosciences 3, e70-e80.

Major DE, Kesslak JP, Cotman CW, Finch CE \& Day JR (1997) Life-long dietary restriction attenuates age-related increases in hippocampal glial fibrillary acidic protein mRNA. Neurobiology of Aging 18, 523-526.

Makrides M, Neumann MA, Byard RW, Simmer K \& Gibson RA (1994) Fatty acid composition of brain, retina, and erythrocytes in breast- and formula-fed infants. American Journal of Clinical Nutrition 60, 189-194.

Marcus J, Auerbach J, Wilkinson L \& Burack CM (1981) Infants at risk for schizophrenia. The Jerusalem Infant Development Study. Archives of General Psychiatry 38, 703-713.

Marin MC, De Tomas ME, Serres C \& Mercuri O (1995) Protein-energy malnutrition during gestation and lactation in rats affects growth rate, brain development and essential fatty acid metabolism. Journal of Nutrition 125, 10171024.

Martin LJ, Furuta A \& Blackstone CD (1998) AMPA receptor protein in developing rat brain: glutamate receptor-1 expression and localization change at regional, cellular, and subcellular levels with maturation. Neuroscience 83, 917-928.

Martinez M (1992) Tissue levels of polyunsaturated fatty acids during early human development. Journal of Pediatrics 120, S129-S138.

Matthews K, Wilkinson LS \& Robbins TW (1996) Repeated maternal separation of preweanling rats attenuates behavioral responses to primary and conditioned incentives in adulthood. Physiology and Behavior 59, $99-107$.

Meberg A (1981) Somatic growth and brain development. Effects of intrauterine malnutrition and hypoxia in mice. Biology of the Neonate 39, 272-284.

Morgane PJ, Austin K, Siok C, LaFrance R \& Bronzino JD (1985) Power spectral analysis of hippocampal and cortical EEG activity following severe prenatal protein malnutrition in the rat. Brain Research 354, 211-218.

Morgane PJ, Austin-LaFrance R, Bronzino J, Tonkiss J, Diaz-Cintra S, Cintra L, Kemper T \& Galler JR (1993) Prenatal malnutrition and development of the brain. Neuroscience and Biobehavioral Reviews 17, 91-128.

Morley R (1996) The influence of early diet on later development. Journal of Biosocial Science 28, 481-487.

Morley R \& Lucas A (1994) Influence of early diet on outcome in preterm infants. Acta Paediatrica, Suppl., 405, 123126.

Morovat A \& Dauncey MJ (1995) Regulation of porcine skeletal muscle nuclear 3,5,3'-triiodothyronine receptor binding capacity by thyroid hormones: modification by energy balance. Journal of Endocrinology 144, $233-242$.

Mortensen PB, Pedersen CB, Westergaard T, Wohlfahrt J, Ewald H, Mors O, Andersen PK \& Melbye M (1999) Effects of family history and place and season of birth on the risk of schizophrenia. New England Journal of Medicine 340, $603-608$.

Nathanielsz PW (1996) Fetal and neonatal environment has influence on brain development. Lancet 347, 314.

Nyirenda MJ \& Seckl JR (1998) Intrauterine events and the programming of adulthood disease: The role of fetal glucocorticoid exposure. International Journal of Molecular Medicine 2, 607-614.

Pastor R, Bernal J \& Rodriguez-Pena A (1994) Unliganded c-erbA/thyroid hormone receptor induces trkB expression in neuroblastoma cells. Oncogene 9, 1081-1089.

Pavey DE \& Widdowson EM (1980) Body lipids of guinea pigs exposed to different dietary fats from mid-gestation to 3 months of age. V. The fatty acid composition of brain lipids at birth. Nutrition and Metabolism 24, 357-366.

Peeling AN \& Smart JL (1994a) Review of literature showing that undernutrition affects the growth rate of all processes in the brain to the same extent. Metabolic Brain Disease 9, 33-42.

Peeling AN \& Smart JL (1994b) Successful prediction of immediate effects of undernutrition throughout the brain growth spurt on capillarity and synapse-to-neuron ratio of cerebral cortex in rats. Metabolic Brain Disease $\mathbf{9 , 8 1 - 9 5 .}$

Petridou E, Koussouri M, Toupadaki N, Youroukos S, Papavassiliou A, Pantelakis S, Olsen J \& Trichopoulos D (1998) Diet during pregnancy and the risk of cerebral palsy. British Journal of Nutrition 79, 407-412.

Phillips DI, Barker DJ, Fall CH, Seckl JR, Whorwood CB, Wood PJ \& Walker BR (1998) Elevated plasma cortisol concentrations: a link between low birth weight and the insulin resistance syndrome? Journal of Clinical Endocrinology and Metabolism 83, 757-760.

Rizzo TA, Metzger BE, Dooley SL \& Cho NH (1997) Early malnutrition and child neurobehavioral development: insights from the study of children of diabetic mothers. Child Development 68, 26-38.

Rushmore J, Luebke J \& Galler JR (1998) Electrophysiological properties of rat hippocampal principal cells are unaltered by prenatal protein malnutrition. Hippocampus 8, 380-389.

Salas M, Torrero C \& Pulido S (1984) Long-term alterations in the maternal behavior of neonatally undernourished rats. Physiology and Behavior 33, 273-278.

Saste MD, Carver JD, Stockard JE, Benford VJ, Chen LT \& Phelps CP (1998) Maternal diet fatty acid composition affects neurodevelopment in rat pups. Journal of Nutrition 128, 740-743.

Schull WJ \& Otake M (1999) Cognitive function and prenatal exposure to ionizing radiation. Teratology 59, 222 - 226.

Seidler FJ, Bell JM \& Slotkin TA (1990) Undernutrition and overnutrition in the neonatal rat: long-term effects on noradrenergic pathways in brain regions. Pediatric Research 27, $191-197$.

Shimohama S, Kamiya S, Taniguchi T, Akagawa K \& Kimura J (1997) Differential involvement of synaptic vesicle and presynaptic plasma membrane proteins in Alzheimer's disease. Biochemical and Biophysical Research Communications 236, 239-242.

Shultz PL, Tonkiss J, Morgane PJ, Bronzino JD \& Galler JR (1995) Effects of an every other day rapid kindling procedure in prenatally protein malnourished rats. Brain Research 682, 35-40. 
Smart JL (1990) Vulnerability of developing brain to undernutrition. Uppsala Journal of Medical Sciences, Suppl., 48, $21-41$.

Smart JL (1991) Critical periods in brain development. CIBA Foundation Symposium 156, 109-124.

Soto-Moyano R, Belmar J, Perez H, Ruiz S \& Hernandez A (1995) Central noradrenergic hyperactivity early in life: a hypothesis on the origin of morpho-functional brain disorders induced by malnutrition. Biological Research 28, $105-$ 111.

Stern WC, Forbes WB, Resnick O \& Morgane PJ (1974) Seizure susceptibility and brain amine levels following protein malnutrition during development in the rat. Brain Research 79, 375-384.

Stewart RJC (1974) Experimental studies on nutrition and brain development. Nutrition 28, 151-162.

Sun XZ, Takahashi S, Fukui Y, Hisano S, Kuboda Y, Sato H \& Inouye M (1999) Different patterns of abnormal neuronal migration in the cerebral cortex of mice prenatally exposed to irradiation. Brain Research. Developmental Brain Research 114, 99-108.

Sze CI, Troncoso JC, Kawas C, Mouton P, Price DL \& Martin LJ (1997) Loss of the presynaptic vesicle protein synaptophysin in hippocampus correlates with cognitive decline in Alzheimer disease. Journal of Neuropathology and Experimental Neurology 56, $933-944$.

Thomas YM, Peeling A, Bedi KS, Davies CA \& Dobbing J (1980) Deficits in synapse-to-neuron ratio due to early undernutrition show evidence of catch-up in later life. Experientia 36, 556-557.

Tonkiss J, Galler J, Morgane PJ, Bronzino JD \& Austin-LaFrance RJ (1993) Prenatal protein malnutrition and postnatal brain function. Annals of the New York Academy of Sciences 678, 215-227.

Uauy R \& de Andraca I (1995) Human milk and breast feeding for optimal mental development. Journal of Nutrition 125, 2278S-2280S

Uauy-Dagach R \& Mena P (1995) Nutritional role of omega-3 fatty acids during the perinatal period. Clinics in Perinatology 22, 157-175.

van Houwelingen AC, Sorensen JD, Hornstra G, Simonis MM, Boris J, Olsen SF \& Secher NJ (1995) Essential fatty acid status in neonates after fish-oil supplementation during late pregnancy. British Journal of Nutrition 74, 723-731.

Wainwright PE, Xing HC, Ward GR, Huang YS, Bobik E, Auestad N \& Montalto M (1999) Water maze performance is unaffected in artificially reared rats fed diets supplemented with arachidonic acid and docosahexaenoic acid. Journal of Nutrition 129, 1079-1089.

Wang W \& Dow KE (1998) Quantitative analysis of mRNA expression of neuron-specific growth-associated genes in rat primary neurons by competitive RT-PCR. Brain Research. Brain Research Protocols 2, 199-208.

Ward GR \& Wainwright PE (1988) Reductions in maternal food and water intake account for prenatal stress effects on neurobehavioral development in B6D2F2 mice. Physiology and Behavior 44, 781-786.

Wasantwisut E (1997) Nutrition and development: other micronutrients' effect on growth and cognition. Southeast Asian Journal of Tropical Medicine and Public Health 28, 78-82.

Wauben IP \& Wainwright PE (1999) The influence of neonatal nutrition on behavioral development: a critical appraisal. Nutrition Reviews 57, 35-44.

Wheal HV, Chen Y, Mitchell J, Schachner M, Maerz W, Wieland H, Rossum DV \& Kirsch J (1998) Molecular mechanisms that underlie structural and functional changes at the postsynaptic membrane during synaptic plasticity. Progress in Neurobiology 55, 611-640.

White P \& Dauncey MJ (1998) Postnatal undernutrition markedly upregulates cardiac $\alpha 1$ and $\alpha 2$ thyroid hormone receptor gene expression. Proceedings of the Nutrition Society 57, 79A.

White P \& Dauncey MJ (1999) Differential expression of thyroid hormone receptor isoforms is strikingly related to cardiac and skeletal muscle phenotype during postnatal development. Journal of Molecular Endocrinology 23, (In the Press).

Widdowson EM, Dauncey MJ, Gairdner DM, Jonxis JH \& Pelikan-Filipkova M (1975) Body fat of British and Dutch infants. British Medical Journal 1, 653-655.

Wiggins RC, Fuller G \& Enna SJ (1984) Undernutrition and the development of brain neurotransmitter systems. Life Sciences 35, 2085-2094.

Woltil HA, van Beusekom CM, Schaafsma A, Muskiet FA \& Okken A (1998) Long-chain polyunsaturated fatty acid status and early growth of low birth weight infants. European Journal of Pediatrics 157, 146-152.

Xu L, Holscher C, Anwyl R \& Rowan MJ (1998) Glucocorticoid receptor and protein/RNA synthesis-dependent mechanisms underlie the control of synaptic plasticity by stress. Proceedings of the National Academy of Sciences USA 95, 3204-3208.

Young CE, Arima K, Xie J, Hu L, Beach TG, Falkai P \& Honer WG (1998) SNAP-25 deficit and hippocampal connectivity in schizophrenia. Cerebral Cortex 8, 261-268.

Zeisel SH (1986) Dietary influences on neurotransmission. Advances in Pediatrics 33, 23-47. 